\title{
An attempt to identify recombinants between two sobemoviruses in doubly infected oat plants
}

\author{
Merike MEIER and Erkki TRUVE* \\ Department of Gene Technology, Tallinn University of Technology, Akadeemia tee 15, 19086 Tallinn, Estonia
}

Recombination in RNA viruses is considered to play a major role as a driving force in virus variability to counterbalance loss in fitness that can be due to the accumulation of detrimental mutations. Studies on mixed infections are pertinent for understanding the role of recombination in virus evolution. They also provide important baseline information for studying the biosafety of plants expressing viral sequences. To investigate the possibility of RNA recombination occurrence between two sobemoviruses under little or no selection pressure, we co-infected test plants with Cocksfoot mottle virus (CfMV) and Ryegrass mottle virus (RGMoV). CfMV and RGMoV were selected because of their overlapping host range and geographical distribution. First, symptom development of both viruses in barley (Hordeum vulgare) and oat (Avena sativa) was examined. Both viruses generated quite strong infection symptoms in oat, but synergism was not detected. RGMoV was lethal for barley, whereas CfMV infection in barley was nearly symptomless. RT-PCR analysis revealed $100 \%$ infection with both viruses in oat but not in barley. Therefore, an RNA recombination study of CfMV and RGMoV was performed in oat. 105 plants were co-inoculated with both viruses and putative recombinational hot spot regions were screened for recombination events by RT-PCR analysis at a sensitivity level down to $0.1-100 \mathrm{pg}$ of viral genomic RNA. No recombination events between the two sobemoviruses were detected.

Keywords: Cocksfoot mottle virus / Ryegrass mottle virus / RNA recombination / RT-PCR

\section{INTRODUCTION}

Recombination between homologous viral genomes is considered to be common in plants during natural coinfection of viruses (Garcia-Arenal et al., 2001). Genome sequencing data, as well as studies on virus gene functions, have suggested frequent recombination of geminiviruses, caulimoviruses, bromoviruses, tobamoviruses, potyviruses, closteroviruses, luteoviruses and their related genera (tombusviruses, poleroviruses and sobemoviruses) during evolution (Hull, 2002).

The unassigned genus Sobemovirus consists of plant viruses with a single (+)-stranded RNA genome whose 5' end is covalently bound to $\mathrm{VPg}$, and packed into icosahedral particles (Hull and Fargette, 2005). The 5' terminus of the sobemovirus genome encodes the nonconserved P1 protein from ORF1 (Tamm and Truve, 2000). The middle part of the sobemovirus genome (encoding Pro-VPg-RdRp) is similar to that of the genus Polerovirus belonging to the family Luteoviridae, whereas the 3' part of the genome - encoding the coat protein $(\mathrm{CP})$ from a subgenomic RNA - is related to the genus Necrovirus belonging to the family Tombusviridae (Hull and Fargette, 2005). The viruses of the genera Polerovirus and Enamovirus are classified in the family Luteoviridae according to their homology with genus Luteovirus at the 3' parts of their genomes, whereas their 5 ' parts are clearly distant from luteoviruses. At the same time, the products of ORF1 and ORF2 of viruses from genus Luteovirus are most similar to those of the viruses of the genus Dianthovirus from the family Tombusviridae (D'Arcy and Domier, 2005). Taking into account all of these homologies, it has been suggested that the key mechanism in the evolution of "the supergroup" composed of luteo-, sobemo- and tombusviruses is RNA recombination (Martin et al., 1990). A recent report of the sequence of Poinsettia cryptic virus described a virus showing a close relationship to poleroviruses within the

\footnotetext{
* Corresponding author: erkki.truve@ttu.ee
} 
first three quarters of its genome, but rather to sobemoviruses in the last quarter. The authors suggested to change the name of the virus to Poinsettia latent mottle virus, and to put it in the new genus Polemovirus (aus dem Siepen et al., 2005).

Sobemoviruses have narrow host ranges. Among the sequenced sobemoviruses, there are three monocotinfecting species: Cocksfoot mottle virus (CfMV), Ryegrass mottle virus (RGMoV) and Rice yellow mottle virus (RYMV). The natural host plants for CfMV are cocksfoot (Dactylis glomerata) and wheat (Triticum aestivum) (Serjeant, 1964). In experimental conditions, it is also propagated in barley (Hordeum vulgare) and oat (Avena sativa). RGMoV has been reported from cocksfoot and annual ryegrass (Lolium multiflorum) (Toriyama et al., 1983). In experimental conditions, it can also infect wheat, oat, barley, perennial ryegrass (Lolium perenne), red fescue (Festuca rubra), foxtail bristlegrass (Setaria italica), and rye (Secale cereale). The host range of Rice yellow mottle virus (RYMV) does not overlap with the previous ones at all. Furthermore, RYMV is occurs in tropical Africa, whereas the other two species are dispersed in areas with moderate climate, like the majority of known sobemoviruses. The geographical distribution of RGMoV and CfMV overlaps at least in Japan.

According to the suggestion that recombinational shuffling of genes and gene blocks has played an important role in the formation of contemporary species of "the supergroup" of luteo-sobemo-tombusviruses, the biosafety of using these viruses for biotech applications, such as viral vectors expressing foreign genes or pathogen-derived virus resistance, must be considered.

To identify recombination potential in the sobemovirus group, 105 oat plants were co-inoculated with CfMV and RGMoV. The experiments were carried out under little or no selection pressure (i.e. non-transgenic plants were infected with two wild-type viruses), to avoid positive selection for escape-recombinations that may reflect the results of selective pressure rather than the mechanism of recombination itself. Also, the real frequency of recombinational events may be underestimated if the recombinants with higher fitness are selected and those with negatively selected are lost (reviewed by Aaziz and Tepfer, 1999). Regions of the -1 ribosomal frameshifting signal and a putative subgenomic RNA promoter were selected to screen for recombination events, because they probably possess (Tamm, 2000) secondary structure elements that have been suggested to be potential hot spots for a RNA recombination. This study is the first survey of recombination between sobemoviruses.

\section{RESULTS}

\section{Symptom development}

In order to evaluate their appropriateness for virus recombination studies, two experimental hosts, oat and barley, were examined for virus propagation and symptom development in the case of single or double infections with wild-type CfMV and RGMoV. In barley, CfMV infection was nearly symptomless, causing slight mottling of leaves, whereas RGMoV induced a rapid yellowing of systemic leaves (Fig. 1A). Infection with RGMoV was usually lethal two weeks after inoculation (Fig. 1B). In oat, the infections of CfMV and RGMoV caused quite strong chlorotic mottling of leaves (Fig. 1A), but with no fatal consequences (Fig. 1B). Oat plants infected with RGMoV became slightly stunted (Fig. 1B), as described previously (Yao et al., 2002). In both hosts, the symptoms of RGMoV prevailed if co-inoculated with CfMV (Fig. 1A). The RTPCR analysis of systemic leaves of co-inoculated plants indicated that both viruses were present in oat, whereas CfMV was absent roughly in half of the doubly inoculated barley plants (Fig. 1C). Therefore, oat plants were chosen for further experiments. Synergistic effects in symptom development were observed neither in barley nor in oat in the case of double infections.

\section{Specificity and sensitivity of RT-PCR}

When the entire genome sequences of CfMV and RGMoV were aligned, the identity was of $48 \%$, with score 481 and $E$ value $\mathrm{e}^{-132}$. This alignment was used to design virusspecific primer pairs for amplifying the regions of the -1 ribosomal frameshifting signal and the putative subgenomic RNA promoter. In the frameshift region, between CfMV (1343-1942 nt) and RGMoV (1527$2136 \mathrm{nt}$ ), the identity was of $53.9 \%$, with score 1681 . In the putative subgenomic RNA promoter region, between CfMV (2818-3380 nt) and RGMoV (3009-3593 nt), the identity was of $50.2 \%$, with score 1421.5 . The largest blocks of sequence identity were $10 \mathrm{bp}$ and $8 \mathrm{bp}$, respectively.

The primers were named as follows: the first letter (C or R), refers to CfMV or RGMoV, sg or fs designate the subgenomic promoter or frameshift region, and 5' or 3' corresponds to the position of the primer relative to the putative recombination hot spot. Specific detection of viruses was achieved both with CfMV- and RGMoVspecific primer pairs when amplifying the regions of the -1 ribosomal frameshifting signal or the putative subgenomic RNA promoter in the RT-PCR analysis of 

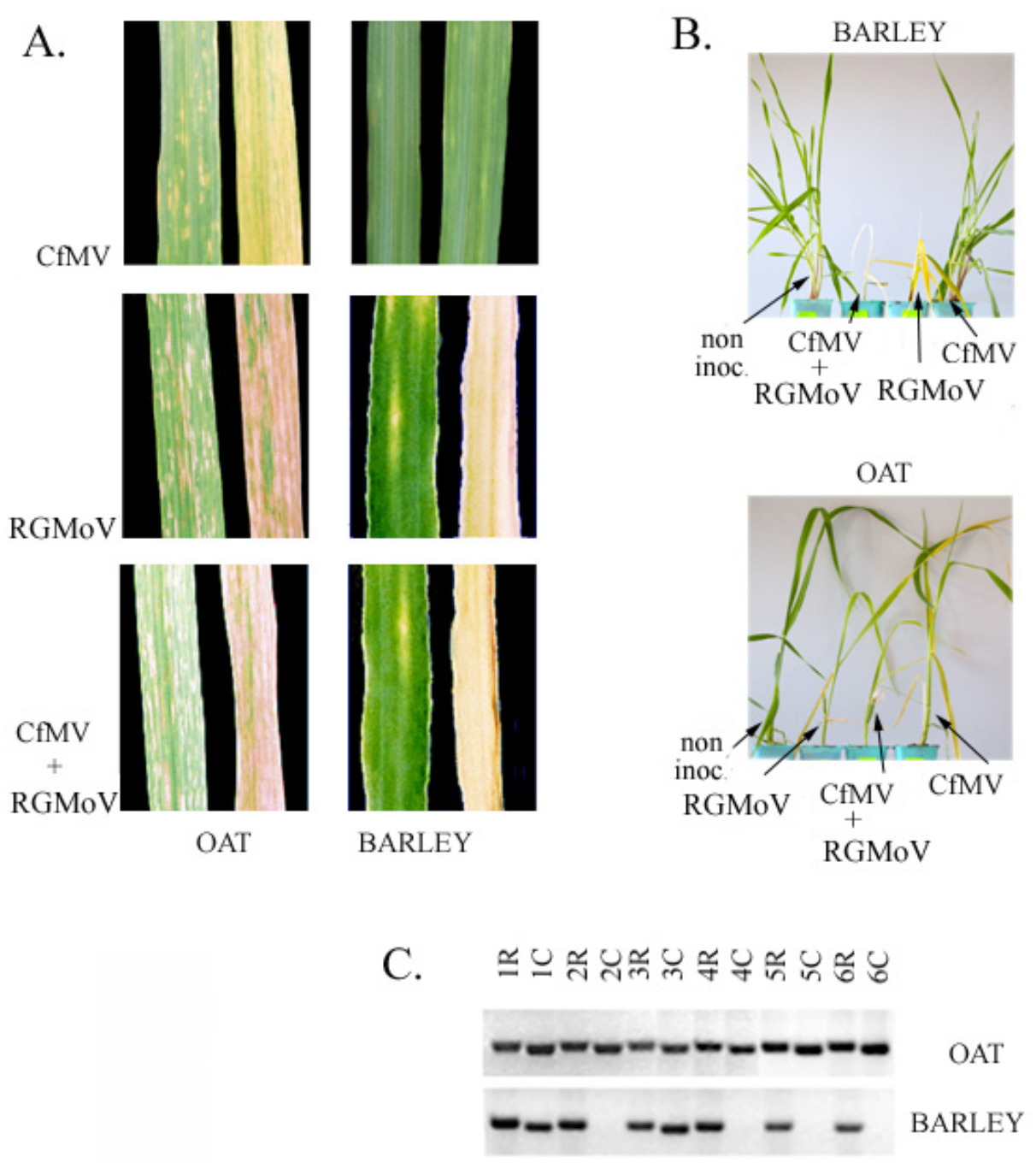

Figure 1. A. Macroscopic symptoms in oat and barley leaves inoculated with CfMV, RGMoV or both at 14 dpi. B. Barley and oat plants infected with CfMV, RGMoV or both at 21 dpi. C. RT-PCR analysis of systemic leaves of 6 plants of oat and barley co-inoculated with CfMV and RGMoV at 21 dpi. Primers Rsg5'+Rsg3' were used to detect RGMoV (R), and primers Cfs5'+Cfs3' were used to detect CfMV (C).

singly infected oat plants. No unspecific amplification was observed with these primer pairs when the RNA extracted from the CfMV-infected plant was artificially mixed with that extracted from the RGMoV-infected plant before using it as a template for RT-PCR (Fig. 2).

Recombinant primer pairs Csg5'+Rsg3', Rsg5'+ Csg3' and Cfs5' +Rfs3' did not amplify any fragment from the RNA isolated from singly CfMV- or RGMoV-infected oats or from the artificial mixture of these two (Fig. 2). Thus, these primer pairs were appropriate for the recombinant virus screen. The primer combination of Rfs5'+Cfs3' amplified several non-specific fragments from the RNA extracted from plant material with a single infection of RGMoV as well as from its mixture with the RNA from CfMV-infected oat. Therefore, the primer pair Rfs5'+Cfs3' was not suitable for a recombination study.

The whole genome alignment of CfMV and RGMoV was also used design and then clone artificial hybrid virus templates (Fig. 3A) that were used to test the sensitivity of recombinant primer pairs. The primer pairs Cfs5'+Rfs3' and Rsg5'+Csg3' had good sensitivity - they detected down to $0.1 \mathrm{pg}$ of the in vitro synthesized recombinant template RNA from the mixture of $0.5 \mu \mathrm{g}$ total RNA of non-inoculated oat (Fig. 3B). In contrast, the 


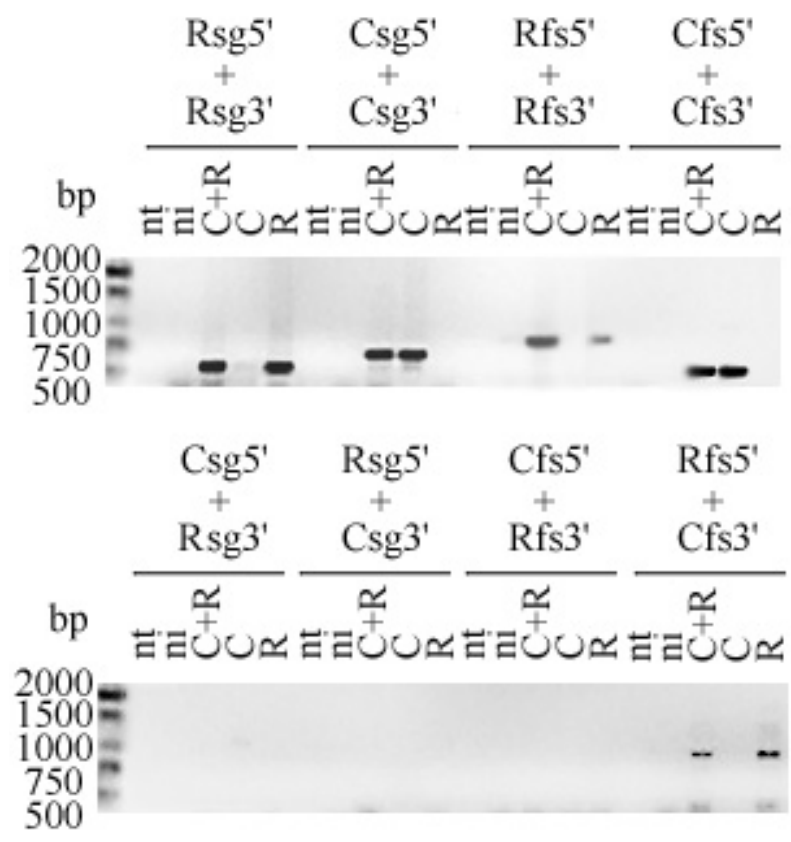

primer pair Csg5' + Rsg3' detected the presence of template RNA in the mixture at a sensitivity level down to only 100 pg (Fig. 3B).

For the recombination study, 105 oat plants were doubly inoculated with CfMV and RGMoV in five groups within three days: 25 plants were co-inoculated simultaneously on day 0 , whereas 20 singly CfMV- or RGMoV-inoculated plants were inoculated with the other virus on day 1 , and 20 of singly CfMV- or RGMoVinoculated plants were inoculated with the other virus on day 2. According to the RT-PCR analysis, 99 of the 105 plants contained both viruses at 7 days post-inoculation (dpi) (Tab. 1). No differences were observed in the development of co-infection when the five inoculation groups were compared. Plant material was collected from the inoculated leaves to obtain an original pool of possible recombinant molecules and to avoid loss of those with lower fitness. However, no RT-PCR products were detected using primer pairs specific to the recombinant viruses at a sensitivity level down to $0.1-100 \mathrm{pg}$ of the recombinant template RNA from any of doubly infected oats (Tab. 1).

\section{DISCUSSION}

Previous in vivo recombination studies on bromo-, carmoand tombusviruses have established that recombination does not occur randomly within viral RNA genomes, but there are recombination hot spots. These include short
Figure 2. Specificity of primer pairs in combinations specific to parental and recombinant viruses. Templates used in RTPCR: nt, no template; ni, RNA extracted from non-inoculated oat; C+R, RNA extracted from CfMV-infected oat mixed with RNA extracted from RGMoV-infected oat; C, RNA extracted from CfMV-infected oat; R, RNA extracted from RGMoVinfected oat.

AU-rich sequences, inter- and intramolecular secondary structures (stem-loop structures and heteroduplexes formed between complementary stretches present in separate RNAs) and cis-acting RNA elements with high affinity toward the viral replicase (5' end replicase pausing sites, replication enhancers, genomic and subgenomic promoters). Also, the presence of nontemplated nucleotides at recombination junction sites is essential (reviewed by White and Nagy, 2004).

In this study, sobemovirus regions of the -1 ribosomal frameshifting signal and the putative subgenomic RNA promoter were selected to screen for potential recombinational hot spots. The -1 ribosomal frameshift signal characteristic of CfMV consists of a slippery sequence (UUUAAAC) and a stem-loop structure several nucleotides downstream from it. It can be found in all sequenced sobemovirus genomes (Tamm and Truve, 2000). The slippery sequence positioned in CfMV at nt 1634-1640 aligned well with the corresponding sequence of RGMoV at nt 1842-1848. In contrast, the exact position of the sobemoviral subgenomic promoter is not known. By analogy with 5' end of the genomic sequence, a transcription start point for subgenomic RNA was suggested to be ACAAA for SBMV, RYMV and LTSV, located a few nucleotides upstream the CP gene start codon (Tamm and Truve, 2000). This sequence motif is not present in CfMV (Tamm and Truve, 2000). In this study, the subgenomic RNA promoter was expected to lie in the range of -150 and $+150 \mathrm{nt}$ from the $\mathrm{CP}$ translation 

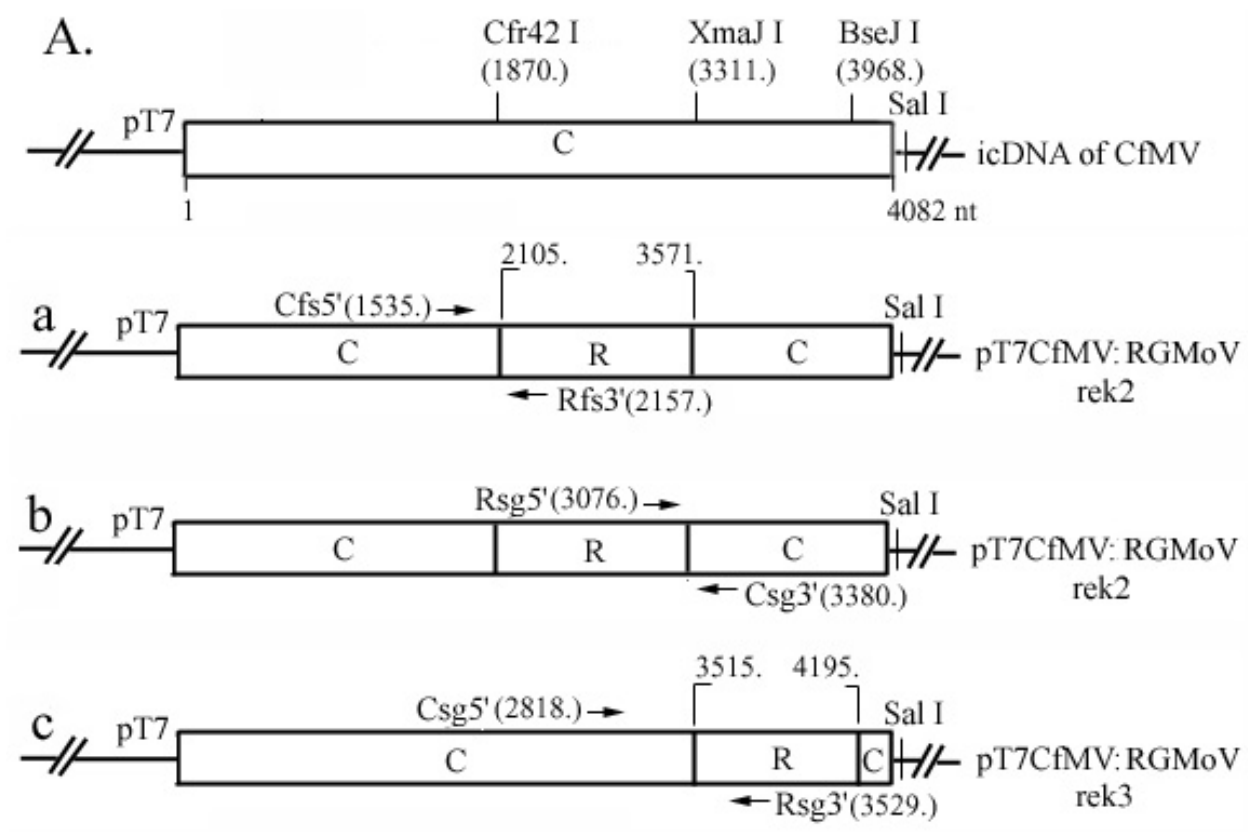

B.

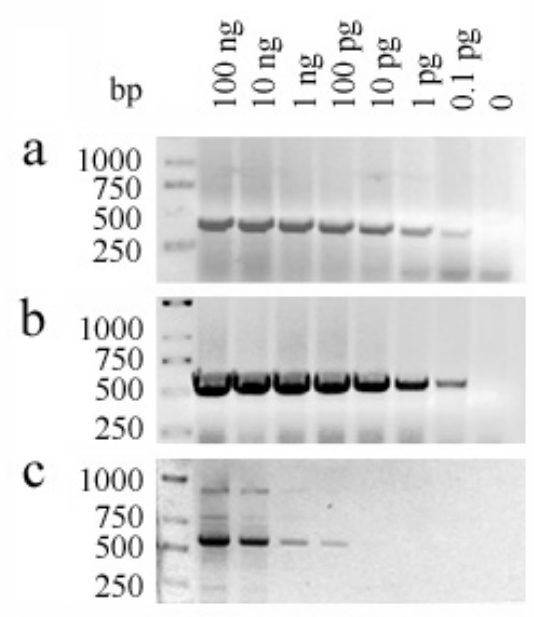

Figure 3. A. Schematic presentation of recombinant CfMV:RGMoV clones constructed for in vitro RNA synthesis. Arrows show primer pairs specific to recombinant viral RNAs. C, CfMV, R, RGMoV. B. Sensitivity of primer pairs (marked with a, b and $c$ according to panel A) specific to recombinant viral RNA. The RT-PCR analysis was performed using primer pairs and in vitro synthesized RNA templates diluted in 10-fold series (from $100 \mathrm{ng}$ to $0.1 \mathrm{pg}$ ). $0.5 \mu \mathrm{g}$ of RNA extracted from non-inoculated oat was added into all RT-PCR reactions to mimic the natural proportions of cellular and viral RNAs.

Table 1. RT-PCR analysis of inoculated oat plants at 7 dpi.

\begin{tabular}{|c|c|c|c|c|c|c|}
\hline \multicolumn{3}{|c|}{ No. of plants infected } & \multicolumn{4}{|c|}{ No. of recombinants detected } \\
\hline $\mathrm{CfMV}^{1}$ & $\mathrm{RGMoV}^{2}$ & $\begin{array}{c}\text { CfMV } \\
+ \\
\text { RGMoV }^{1,2}\end{array}$ & $\begin{array}{l}\text { Rfs5 } \\
+ \\
\text { Cfs3 }\end{array}$ & $\begin{array}{c}\text { Cfs5 } \\
+ \\
\text { Rfs3 }\end{array}$ & $\begin{array}{c}\text { Rsg5, } \\
+ \\
\text { Csg3 }\end{array}$ & $\begin{array}{c}\text { Csg5' } \\
+ \\
\text { Rsg3' }\end{array}$ \\
\hline $100 / 105$ & $102 / 105$ & $99 / 105$ & $\mathrm{NS}^{3}$ & 0/99 & $0 / 99$ & $0 / 99$ \\
\hline
\end{tabular}

start point, as characteristic of other plant viral subgenomic promoters (reviewed by Miller and Koev, 2000).

All together, the areas between $1535 \mathrm{nt}$ and $1967 \mathrm{nt}$, as well as between $2818 \mathrm{nt}$ and $3380 \mathrm{nt}$ in the CfMV genome, and between $1440 \mathrm{nt}$ and $2157 \mathrm{nt}$, as well as between $3076 \mathrm{nt}$ and $3529 \mathrm{nt}$ in the RGMoV genome, were screened by RT-PCR for possible recombination 
products, using combinations of appropriate primer pairs. However, when the 99 CfMV and RGMoV co-infected oat plants were screened, no RT-PCR products were detected using primer pairs specific to recombinant viruses at a sensitivity level down to $0.1-100 \mathrm{pg}$ of the recombinant template RNA. It remains unknown whether recombination could occur elsewhere between the two genomes.

No intra-specific or inter-specific recombinant sobemoviruses have been described so far. Based on the phylogenetic analysis of 14 RYMV full-length isolates and 58 capsid protein genes sequences, it has been concluded that RYMV evolved in the absence of recombination events (Chare and Holmes, 2006; Fargette et al., 2004). Similarly, on the basis of the phylogenetic comparison of six sobemovirus genomes, including CfMV, RYMV, Lucerne transient streak virus (LTSV), Sesbania mosaic virus (SeMV), Southern cowpea mosaic virus (SCPMV), and Southern bean mosaic virus (SBMV), it was suggested that recombination is neither frequent nor significant in the sobemovirus group (Lokesh et al., 2001).

On the other hand, the presence of viral defective interfering molecules (DI) is considered to be proof of a replicase-driven template switching mechanism (reviewed by White and Morris, 1999). Five DI RNAs of CfMV have been found, corresponding to 35-40 nucleotides of the 5'proximal end of genomic RNA linked with 850-950 nucleotides of the 3' terminus (Mäkinen et al., 2000).

There can be various reasons for the poor detection of recombinant virus molecules. Generally, five steps must be passed to generate a viable recombinant between different viruses or virus strains: co-infection of the host, co-infection of the cell, replication, template switching, and selection (reviewed by Worobey and Holmes, 1999). Since the length of a replication cycle of CfMV and RGMoV is not known, co-inoculations were performed in five groups within three days to provide the possibility of simultaneous replication and potential recombination between these two viruses. No differences were observed in the development of co-infection in these five inoculation groups. The results presented here are based on the RT-PCR analysis, which confirm the co-infection of the same leaf and replication of both viruses. However, co-infection of the same cell may only be assumed. If there exist any restrictions (e.g. cross-protection between related viruses, reviewed by Roossinck, 2005) for the coinfection of the cell, then it would automatically diminish a chance for recombination events and further selection. Therefore, it would be necessary to study the colocalization of CfMV and RGMoV at the cellular level using specific antibodies or any other application to distinguish them in the co-infected plants.

Discrete distribution of related virus strains or species has been described at least for Tobacco mosaic virus (TMV), Alfalfa mosaic virus (AMV), Potato virus X (PVX), Plum pox virus (PPV), and Tobacco vein mottling virus (TVMV) (Dietrich and Maiss, 2003; Divéki et al., 2002; Hull and Plaskitt, 1970; McKinney, 1929). Spatial separation patterns with very few cells expressing both viruses have been documented for different potyvirus species - PPV, TVMV and Clover yellow vein virus (CIYVV) (Dietrich and Maiss, 2003). However, there is substantial evidence for intra- and interspecific recombination between potyviruses derived from sequencing and phylogenetic analysis of natural virus populations (Bousalem et al., 2000; Cervera et al., 1993; Chare and Holmes, 2006; Desbiez and Lecoq, 2004; Fanigliulo et al., 2005; Ohshima et al., 2002; Tan et al., 2004; Zhong et al., 2005).

Studies on plant virus recombination demonstrate that the properties of the viral replicase and several host factors also play a role in RNA recombination. When complementary RNA synthesis and template switching of carmo(Turnip crinkle virus, TCV) and tombusvirus (Cucumber necrosis virus, $\mathrm{CNV}$ ) replicases were tested in vitro, $\mathrm{TCV}$ replicase was stimulated by a $\mathrm{CNV}$ replication enhancer element, whereas $\mathrm{CNV}$ replicase discriminated against the TCV replication enhancer element (Cheng et al., 2005). Tomato bushy stunt virus (TBSV) replicase can conduct RNA recombination at an AU-rich signal that constitutes a recombination hot spot in Brome mosaic virus (BMV) and retroviruses (Shapka and Nagy, 2004). Mutations within the RNA-binding domains of a replicase affect the frequency of recombination - for CNV replicase it was shown that mutations could both delay or accelerate the formation of recombinants (Panaviene and Nagy, 2003). These studies imply that recombination between two viruses and post-recombinational amplification depends on the template switching ability of a specific replicase.

The recombination potential of TBSV, Turnip mosaic virus (TuMV), Yam mosaic virus (YMV) and BMV has been shown to depend on the host (Bousalem et al., 2000; Desvoyes and Scholthof, 2002; Dzianott and Bujarski, 2004; Ohshima et al., 2002). Screening the recombination efficiency of TBSV using a yeast single-knockout library revealed that host genes involved in RNA degradation were suppressing the generation of new viral RNA recombinants. In contrast, genes contributing to the intracellular transport of proteins were identified as viral RNA recombination accelerators (Serviene et al., 2005; Serviene et al., 2006). 
In this study, approximately one quarter of the CfMV and RGMoV genomes were monitored with highly sensitive and specific RT-PCR for the generation of recombinant molecules in co-inoculated oat plants. No recombination was detected between the two sobemoviruses in the regions of the -1 ribosomal frameshifting signal and a putative subgenomic RNA promoter. These regions were selected because of their content of secondary structures and homologous blocks (8-10 bp). The priming between the donor and acceptor strands as well as re-initiation of the dissociated replicase/ nascent RNA complex have specific requirements. For example, CNV replicase favors base-paired regions of 4 5 bp in length, being less effective with shorter or longer regions (Cheng et al., 2002). In contrast, recombination between two cucumoviruses (Bromoviridae), Cucumber mosaic virus (CMV) and Tomato aspermy virus (TAV), occurred more frequently in longer blocks, and particularly in ones of at least 15-20 identical nucleotides (De Wispelaere et al., 2005; Suzuki et al., 2003). As no recombinants were detected between the two sobemoviruses, it is not clear whether the reason is the extent and/or the content of identical blocks or not. It was surprising that no recombination events in the putative subgenomic promoter area were identified, as the evolution of Pro-VPg-RdRp/CP region in the "supergroup" of luteo-sobemo-tombusviruses is modular (aus dem Siepen et al., 2005; Gibbs and Cooper, 1995; Martin et al., 1990; Mayo and Jolly, 1991; Mayo and Ziegler-Graff, 1996; Miller and Rasochova, 1997; Moonan and Mirkov, 2002; Moonan et al., 2000). Thus, although the evolutionary analysis supports the idea of frequent recombinations within this supergroup, this study was unable to confirm that RNA recombinations take place during the replication of sobemoviruses.

\section{MATERIALS AND METHODS}

\section{Plants, viruses and virus inoculation}

Oat cv. Jaak and barley cv. Kymppi were grown in soil mix (vermiculite:peat:soil, 1:1:2) in a climate chamber $(60 \%$ relative humidity, $16 \mathrm{~h}$ light at $23{ }^{\circ} \mathrm{C}, 8 \mathrm{~h}$ dark at $16{ }^{\circ} \mathrm{C}$ ).

CfMV Norwegian isolate (Mäkinen et al., 1995) and RGMoV Japanese isolate (obtained from MAFF GeneBank, 307043) were used throughout the study. The stocks of infected plant material were frozen in liquid nitrogen and stored at $-70^{\circ} \mathrm{C}$.

The inoculums were prepared by grinding symptomexpressing leaves from the stock of frozen material in a mortar with $1 \mathrm{ml} 100 \mathrm{mM}$ phosphate buffer $(\mathrm{pH}=7.0)$, supplemented with $0.5 \%$ celite per $1 \mathrm{~g}$ of leaf material. $50 \mu \mathrm{l}$ of freshly prepared sap containing CfMV or RGMoV or a 1:1 mixture of both inoculums was rubbed onto the leaves of 2-leaf stage plants 10 days after sowing. Six plants of barley and oat, respectively, were used with each inoculum in parallel for monitoring symptom development. In the recombination study, 105 oat plants were mechanically inoculated with CfMV and RGMoV in five groups. On day 0, 25 plants were co-inoculated with both viruses, 40 plants were singly inoculated with RGMoV and 40 with CfMV. Half of the singly inoculated plants were inoculated with the other virus on day 1 and another half on day 2 .

\section{RNA extraction}

$0.2 \mathrm{~g}$ of inoculated leaf material was harvested at $7 \mathrm{dpi}$, followed by total RNA extraction according to Logemann et al. (1987). Systemically infected upper leaves of doubly inoculated oat and barley were collected at $21 \mathrm{dpi}$. The integrity of extracted RNA was checked by electrophoresis in a $6 \%$ formaldehyde, $0.8 \%$ agarose gel buffered with $1 \times$ MOPS $\mathrm{pH}$ 7.0.

\section{Sequence alignment}

The nucleotide sequences of CfMV (GeneBank accession no. Z48630) and RGMoV (GeneBank accession no. AB040446) were aligned pairwisely using NCBIBLAST2 version BLASTN 2.2.4 (Tatusova and Madden, 1999). To make the alignment, the reward for match was raised (from 1 to 2 ) and the penalty for mismatch was lowered (from -2 to -1 ). Based on this alignment, CfMVand $\mathrm{RGMoV}$-specific primer pairs were designed to amplify the areas of the -1 ribosomal frameshifting signal and the putative subgenomic RNA promoter.

The same alignment was used to design primers for the amplification of RGMoV cDNAs, in order to exchange them to the corresponding CfMV sequences in the CfMV infectious cDNA (icDNA) clone.

\section{Plasmids}

The cDNA fragments of RGMoV were generated from total RNA isolated from RGMoV infected plants by RTPCR, using primers 5'REK2 (5'-AGAGCCGGCAGGCAGATTCCGC-3') and 3'REK2 (5'-GACCTAGGAGAGCACCGTGCCG-3') to amplify nt 2105 to 3571 (cDNA2), 5'REK3 (5'-CATCCTAGGTTAGTACGCGTCACAT-3') and 3'REK3 (5'-GAGATTGGTATCCCCCTACGCTAG-3') to amplify nt 3515 to 4195 
(cDNA3). The restriction endonuclease sites (PdiI, $X m a J I, B s e J I)$ flanking the RGMoV sequence are shown in italics. All the cDNAs generated were inserted into the pTZ57R/T cloning vector (Fermentas) and sequenced.

To construct recombinant CfMV:RGMoV molecules (Fig. 3A), the CfMV icDNA (Meier et al., 2006) was linearized with $C f r 42 I$, and the cohesive ends were filled by T4 DNA polymerase (Fermentas) treatment. RGMoV cDNA2 digested with Bsp68I and XmaJI was ligated into CfMV icDNA, cut by $C f r 42 I$ and XmaJI to create pT7CfMV:RGMoVrek2. pT7CfMV:RGMoVrek3 was obtained by inserting XmaJI and BseJI digested RGMoV cDNA3 into similarly cut CfMV icDNA.

\section{RT-PCR}

SuperScript One-Step RT-PCR kit with Platinum Taq Polymerase (Invitrogen) was used throughout the study. The reactions were carried out as suggested by the manufacturer: first-strand cDNA synthesis was accomplished in $30 \mathrm{~min}$ at $55^{\circ} \mathrm{C}$, PCR was carried out in 30 cycles $\left(15 \mathrm{sec}\right.$ at $94^{\circ} \mathrm{C}, 30 \mathrm{sec}$ at $55^{\circ} \mathrm{C}, 30 \mathrm{sec}$ at $\left.72{ }^{\circ} \mathrm{C}\right)$ after the 2 min denaturation at $94^{\circ} \mathrm{C}$. A $10 \mathrm{~min}$ incubation at $72{ }^{\circ} \mathrm{C}$ was performed at the end of the program.

pT7CfMV:RGMoVrek2 and pT7CfMV:RGMoVrek3 were linearized with SalI and used as templates for RNA synthesis carried out with T7 RNA polymerase (Fermentas). Thereafter, template DNA was degraded with DNase I (Ambion). RNA was purified using the RNAEasy kit (Qiagen) and quantified. The 10-fold serial dilutions of in vitro transcribed RNA were mixed with $0.5 \mu \mathrm{g}$ of total plant RNA extracted from non-infected oat leaves to measure the sensitivity of RT-PCR for the detection of recombinant virus molecules.

pT7CfMV:RGMoVrek2 was used to test the sensitivity of the primer pair of Cfs5' (5'-AGCTGAGGCGTTGCGTGTCG-3' corresponding to CfMV nt 1535 to 1554) and Rfs3' (5'-CTCGGCACGCGCTGTCG-3' complementary to RGMoV nt 2157 to 2141 ) as well as the sensitivity of the primer pair of Rsg5' (5'-CGGACATACGTGAGCGGGAG-3' corresponding to RGMoV nt 3076 to 3095) and Csg3' (5'-CAATGCAGCGGGTGACACAA3' complementary to CfMV nt 3380 to 3361), pT7CfMV:RGMoVrek3 was used to test the sensitivity of the primer pair of Csg5' (5'-GGTCGATGATGCTCCCAGGA-3' corresponding to CfMV nt 2818 to 2837) and Rsg3' (5'-TGTGACGCGTACTAAAGAGCCA-3' complementary to RGMoV nt 3529 to 3508).

\section{ACKNOWLEDGEMENTS}

The RGMoV Japanese isolate was obtained from the MAFF Genebank. M.-A. Laane and C. Sarmiento are acknowledged for critical reading of the manuscript. S. Nõu is appreciated for excellent plant care. This work was supported by the European Commission grant QLK3CT-2000-00361 and the Estonian Science Foundation grant 5909.

Received December 30, 2005; accepted May 30, 2006.

\section{REFERENCES}

Aaziz R, Tepfer M (1999) Recombination in RNA viruses and in virus-resistant transgenic plants. J. Gen. Virol. 80: 13391346

aus dem Siepen M, Pohl JO, Koo B-J, Wege C, Jeske H (2005) Poinsettia latent virus is not a cryptic virus, but a natural polerovirus-sobemovirus hybrid. Virology 336: 240250

Bousalem M, Douzery EJP, Fargette D (2000) High genetic diversity, distant phylogenetic relationships and intraspecies recombination events among natural populations of Yam mosaic virus: a contribution to understanding potyvirus evolution. J. Gen. Virol. 81: 243-255

Cervera MT, Riechmann JL, Martin MT, Garcia JA (1993) 3'-terminal sequence of the Plum pox virus PS and o6 isolates: evidence for RNA recombination within the potyvirus group. J. Gen. Virol. 74: 329-334

Chare ER, Holmes EC (2006) A phylogenetic survey of recombination frequency in plant RNA viruses. Arch. Virol. 151: 933-946

Cheng C-P, Panavas T, Luo G, Nagy PD (2005) Heterologous RNA replication enhancer stimulates in vitro RNA synthesis and template-switching by the carmovirus, but not by the tombusvirus RNA-dependent RNA polymerase: implication for modular evolution of RNA viruses. Virology 341: 107121

D'Arcy CJ, Domier LL (2005) Family Luteoviridae. In: Fauquet CM, Mayo MA, Maniloff J, Desselberger U, Ball LA, eds, Virus Taxonomy. Eighth Report of the International Committee on Taxonomy of Viruses, Elsevier, pp 891-900

Desbiez C, Lecoq H (2004) The nucleotide sequence of Watermelon mosaic virus (WMV, Potyvirus) reveals interspecific recombination between two related potyviruses in the 5' part of the genome. Arch. Virol. 149: 1619-1632

Desvoyes B, Scholthof HB (2002) Host-dependent recombination of a Tomato bushy stunt virus coat protein mutant yields truncated capsid subunits that form virus-like complexes which benefit systemic spread. Virology 304: 434-442

De Wispelaere M, Gaubert S, Trouilloud S, Belin C, Tepfer M (2005) A map of diversity of RNA3 recombinants 
appearing in plants infected with Cucumber mosaic virus and Tomato aspermy virus. Virology 331: 117-127

Dietrich C, Maiss E (2003) Fluorescent labeling reveals spatial separation of potyvirus populations in mixed infected Nicotiana benthamiana plants. J. Gen. Virol. 84: 2871-2876

Divéki Z, Salánki K, Balázs E (2002) Limited utility of blue fluorescent protein in monitoring plant virus movement. Biochimie 84: 997-1002

Dzianott A, Bujarski JJ (2004) Infection and RNA recombination of Brome mosaic virus in Arabidopsis thaliana. Virology 318: 482-492

Fanigliulo A, Comes S, Pacella R, Harrach B, Martin DP, Crescenzi A (2005) Characterization of Potato virus $Y$ nnp strain inducing veinal necrosis in pepper: a naturally occurring recombinant strain of PVY. Arch. Virol. 150: 709720

Fargette D, Pinel A, Abubakar Z, Traoré O, Brugidou C, Fatogoma S, Hébrard E, Choisy M, Séré Y, Fauquet C, Konaté G (2004) Inferring the evolutionary history of Rice yellow mottle virus from genomic, phylogenetic, and phylogeographic studies. J. Virol. 78: 3252-3261

Garcia-Arenal F, Fraile A, Malpica JM (2001) Variability and genetic structure of plant virus populations. Annu. Rev. Phytopathol. 39: 157-186

Gibbs MJ, Cooper JI (1995) A recombinational event in the history of luteoviruses probably induced by base-pairing between the genomes of two distinct viruses. Virology 206: $1129-1132$

Hull R (2002) Matthew's Plant Virology, Academic Press, pp 352-372, 746-812

Hull R, Fargette D (2005) Genus Sobemovirus. In: Fauquet CM, Mayo MA, Maniloff J, Desselberger U, Ball LA, eds, Virus Taxonomy. Eighth Report of the International Committee on Taxonomy of Viruses, Elsevier, pp 885-890

Hull R, Plaskitt A (1970) Electron microscopy on the behavior of two strains of alfalfa mosaic virus in mixed infections. Virology 42: 773-776

Logemann J, Schell J, Willmitzer L (1987) Improved method for the isolation of RNA from plant tissues. Anal. Biochem. 163: $16-20$

Lokesh GL, Gopinath K, Sateshkumar PS, Savithri HS (2001) Complete nucleotide sequence of Sesbania mosaic virus: a new virus species of the genus Sobemovirus. Arch. Virol. 146: 209-223

Mäkinen K, Tamm T, Næss V, Truve E, Puurand Ü, Munthe T, Saarma M (1995) Characterization of cocksfoot mottle sobemovirus genomic RNA and sequence comparison with related viruses. J. Gen. Virol. 76: 2817-2825

Mäkinen K, Generozov E, Arshava N, Kaloshin A, Morozov S, Zavriev S (2000) Detection and characterization of defective interfering RNAs associated with cocksfoot mottle sobemovirus. Mol. Biol. (Moscow) 34: 291-296

Martin RR, Keese PK, Young MJ, Waterhouse, PM, Gerlach WL (1990) Evolution and molecular biology of luteoviruses. Annu. Rev. Phytopathol. 28: 341-363
Mayo MA, Jolly CA (1991) The 5'-terminal sequence of potato leafroll virus RNA: evidence of recombination between virus and host RNA. J. Gen. Virol. 72: 2591-2595

Mayo MA, Ziegler-Graff V (1996) Molecular biology of luteoviruses. Adv. Virus Res. 46: 413-460

McKinney HH (1929) Mosaic disease in Canary Islands, West Africa and Gibraltar. J. Agr. Res. 39: 557-578

Meier M, Paves H, Olspert A, Tamm T, Truve E (2006) P1 protein of Cocksfoot mottle virus is indispensable for systemic spread of the virus. Virus Genes 32: 321-326

Miller WA, Koev G (2000) Synthesis of subgenomic RNAs by positive-strand RNA viruses. Virology 273: 1-8

Miller WA, Rasochova L (1997) Barley yellow dwarf viruses. Annu. Rev. Phytopathol. 35: 167-190

Moonan F, Mirkov TE (2002) Analyses of genotypic diversity among North, South, and Central American isolates of Sugarcane yellow leaf virus: evidence for Colombian origins and for intraspecific spatial phylogenetic variation. J. Virol. 76: $1339-1348$

Moonan F, Molina J, Mirkov TE (2000) Sugarcane yellow leaf virus: an emerging virus that has evolved by recombination between luteoviral and poleroviral ancestors. Virology 269: 156-171

Ohshima K, Yamaguchi Y, Hirota R, Hamamoto T, Tomimura K, Tan Z, Sano T, Azuhata F, Walsh JA, Fletcher J, Chen J, Gera A, Gibbs A (2002) Molecular evolution of Turnip mosaic virus: evidence of host adaptation, genetic recombination and geographical spread. J. Gen. Virol. 83: $1511-1521$

Panaviene Ž, Nagy PD (2003) Mutations in the RNA-binding domains of tombusvirus replicase protein affect RNA recombination. Virology 317: 359-372

Roossinck M (2005) Symbiosis versus competition in plant virus evolution. Nat. Rev. Microbiol. 3: 917-924

Serjeant EP (1964) Cocksfoot mottle virus. Plant Pathol. 13: 23-24

Serviene E, Shapka N, Cheng C-P, Panavas T, Phuangrat B, Baker J, Nagy PD (2005) Genome-wide screen identifies host genes affecting viral RNA recombination. Proc. Natl. Acad. Sci. USA 102: 10545-10550

Serviene E, Jiang Y, Cheng C-P, Baker J, Nagy PD (2006) Screening of the yeast yTHC collection identifies essential host factors affecting tombusvirus RNA recombination. $J$. Virol. 80: 1231-1241

Shapka N, Nagy PD (2004) The AU-rich RNA recombination hot spot sequence of Brome mosaic virus is functional in tombusviruses: implications for the mechanism of RNA recombination. J. Virol. 78: 2288-2300

Suzuki M, Hibi T, Masuta C (2003) RNA recombination between cucumoviruses: possible role of predicted stem-loop structures and an internal subgenomic promoter-like motif. Virology 306: 77-86

Tamm T (2000) Cocksfoot mottle virus: the genome organisation and translational strategies. $\mathrm{PhD}$ thesis. University of Tartu, Estonia 
Tamm T, Truve E (2000) Sobemoviruses. J. Virol. 74: 62316241

Tan Z, Wada Y, Chen J, Ohshima K (2004) Inter- and intralineage recombinants are common in natural populations of Turnip mosaic virus. J. Gen. Virol. 85: 2683-2696

Tatusova TA, Madden TL (1999) Blast 2 sequences - a new tool for comparing protein and nucleotide sequences. FEMS Microbiol. Lett. 174: 247-250

Toriyama S, Mikoshiba Y, Doi Y (1983) Ryegrass mottle virus, a new virus from Lolium multiflorum in Japan. Ann. Phytopathol. Soc. Japan 49: 610

White KA, Morris TJ (1999) Defective and defective interfering RNAs of monopartite plus-strand RNA plant viruses. Curr. Top. Microbiol. 239: 1-17
White KA, Nagy PD (2004) Advances in the molecular biology of tombusviruses: gene expression, genome replication and recombination. Prog. Nucleic Acid Res. 78: 187-226

Worobey M, Holmes EC (1999) Evolutionary aspects of recombination in RNA viruses. J. Gen. Virol. 80: 2535-2543

Yao N, Imai S, Tada Y, Nakayashiki H, Tosa Y, Park P, Mayama S (2002) Apoptotic cell death is a common response to pathogen attack in oats. Mol. Plant Microbe Int. 15: 1000 1007

Zhong Y, Guo A, Li C, Zhuang B, Lai M, Wei C, Luo J, Li Y (2005) Identification of a naturally occurring recombinant isolate of Sugarcane mosaic virus causing maize dwarf mosaic disease. Virus Genes 30: 75-83

To access this journal online: www.edpsciences.org 